\title{
Gender (Mis)-Representation: in Defense of Feminist Language
}

\author{
Happiness Uduk \\ Department of English, Faculty of Arts, University of Uyo, PMB 1017, Uyo, Nigeria.
}

\begin{abstract}
Gender studies has produced new discoveries about the psychology of men and women alike in terms of attitude, character and emotional leaning. The women-folk seem to be at the receiving end of the findings as they are often labeled as inherently emotional and irrational in their choice of words and actions. This paper inquires whether this (mis)representation of women is in tandem with the results on ground that argue that both gender use language differently (Lakoff 1975; Holmes 1984; Baron 1986; Coates 2004). The paper concludes that feminist expressions through words is not to be interpreted as a deficiency, but an emotional outburst of their humanity, just like it occurs in men too and that both gender complement rather than diminish the other.
\end{abstract}

Keywords: Emotion, Feminism, Gender, Deficiency, (Mis) representation, Stereotype, Language.

DOI: $10.7176 / J L L L / 53-09$

\section{Introduction}

Feminism as a movement does not have a long history. However, in the short period that it has flourished, myriads of heated debates have been advanced by her adherents and believers. The agitation is that the womenfolk especially, have been long relegated to the background by male chauvinists based on arguments about (biological) superiority. They argue that this trend can be observed in the history of the sciences, politics and philosophy where women's presence seems to be negligible in terms of contributions. Writing along this line, Uma (1999) avers:

It is a particular manifestation of the general insight that the nature of women's experiences as individuals and as social beings, their contributions to work, culture, knowledge and their history and political interest have been systematically ignored or misrepresented by mainstream discourse in different areas (132).

The exclusion of the women-folk, either overtly or covertly in critical areas of human activities, is at the centre of the feminist movement. This, to them, is inequality and must be resisted, especially when Beauvoir (1970) makes such remarks as "representation of the world, like the world itself, is the work of men; they describe it from their own point of view (p.161)"

Gender studies or movement spiraled into looking into diverse variables that inform the peculiar nature of the man and woman; especially from the standpoint of personality and receptivity. Thus, there are a lot of factors that shape one's personality ranging from belief system to environment, social relations, customs and traditions.

To this end, it only becomes appropriate to re-examine the language of the woman, albeit in a defensible manner, in order to establish the truth that the language of the woman, to a large extent, is shaped and influenced by a lot of factors that do not necessarily have a basis on the gender of the woman as thinkers like Aristotle will affirm; hence it is enough wrong to misrepresent the woman in a light that is further fraught with error. This is the sole aim of this work. Let us now turn to feminism and language.

\section{Feminism and Language}

Language has severally been viewed as a collection of words, phrases, and sentences. It is further regarded as a structure of forms and concepts based on a system of roles that determine their interrelations, arrangement, and organization. By this, language is abstract in nature, hence Ojong (2011) states that: 
In the art of communication, we do use language either as spoken or written words, gestures and symbols of one kind or another all of which are intended to signify to others something which we experience internally within ourselves or externally (3).

The submission of Ojong above is very apt and touches on a wide range of issues as far as this discourse is concerned. Feminism therefore, it must be established, is pursued and executed in language. Language becomes the constructive tool used to press home certain ideals, praises, virtues, resentments, values, inequalities and so on. And arguments are constructed in language as Quine (1953) observes, “... a sentence as one in which all speakers of the language give the same verdict when given the same concurrent stimulation" (p.87). Thus, a closer look at variants of Feminist theories and thoughts will affirm this position.

There are many variant forms of feminism some of which are: Afro-American Feminists, Essentialist Feminism, Evolutionary Feminism, Existential Feminism, Liberal Feminism, Marxist Feminism, and Psychoanalytic Feminism. One thing that ties all of them together is the belief in the argument that women are as much important as men if not more.

Though feminist movements vary in strategies, affiliations and goals, they however place high premium on the force of communication of their beliefs and convictions, which are often critical in order for them to gain superior arguments. This is where the words "he" and "man" become questionable as to their status of being gender-neutral. Frye (1983) argues that, "sex marking" is vital and imperative viz :

If I am writing a book, review, the use of personal pronouns to refer to the author creates the need to know whether that person's reproductive cells are the sort which produce ova or the sort which produce sperm (p. 22).

For Frye, it is imperative to have an idea of which reproductive organ the writer is endowed with as this has a way of influencing his/her perspective. That is, an understanding of the gender of the writer would be pivotal to interpreting the piece appropriately.

Since Language also functions as an important tool in the hands of its users, women use it as a two-edged sword to advance their course of audacity and justice on the one hand, and to clarify certain erroneous misgivings about mainstream activities that create a gap between the male and the female worldview. Spender(1985) corroborates this point when she avers that "there is sexism in language, it does enhance the position of males, and males have had control over the production of cultural forms" (p.144).

Let us now examine one important aspect of this discussion which is: Language as Gender Neutral. This will set the tone for the defense of feminist language.

\section{Is Language Gender Neutral?}

Language as a means of communication is employed by both the male and female. But the contention here is whether there are certain words or symbols that make up language that is peculiar to male or female. There are a lot of neutral terms that inform everyday language. However, every language seems to reflect the prejudices of the society in which it evolved and English for instance, through most of its history is male-centred with a patriarchal history and society.

Assigning masculine gender to neutral terms is one practice that feminists frown at. For example, "man" was once a generic word referring to all human beings, but it has gradually narrowed in meaning to become a word that refers to adult male human beings; also the pronoun "her" seems to be taking the place of "man" to refer to all human beings and other inanimate beings.

Apart from language having a gender connotation, like 'business man/woman' it can also be manipulated to favour certain prejudices and encode either a male/female worldview examples of which are the terms: sex, foreplay, rape, sexual harassment and so on. Nevertheless, it seems as though it would be difficult to severe gender completely from language because of the peculiarity of the communication involving who or what.

The question to be asked here is: why should gender classification in language become an issue? The answer will resonate in a position such as this held by Calvet (1998): 
... the history of the boat cannot be separated from the history of its uses, that there is a dialectic relationship between the two. It is just the same with language. In describing it from a strictly formal point of view, one is describing a code, a structure that can be compared to a boat at moorings or in dry dock. But in the same way that boats are linked to the history of man, language is directly involved in the world and linguistics should take this into account (p.xiv - xv).

Language, though a tool for communication, reflects several dynamics that have different stratifications. Before its manipulation to achieve certain purposes, it first exists. Hence, language it seems is being taken advantage of in order to perpetuate certain gains or advantage. Language has a history which is directly linked to the social, political and cultural life of a people. It is an instrument that helps humans in talking about the world.

The neutrality of language therefore becomes a question of clearly eliminating the wrong approach or use of language. By doing this, it becomes imperative to ask what is being intended or what is it to be achieved when language is manipulated?

These said, another aspect of the issue is to do an analysis of the supposedly gender-neutral use of terms like "her" and "man". This is because these terms are held to have gender specific meanings and therefore are gender-neutral. For example: when a student comes into the room, he should pick up a handout and man is a primate.

The word "he" and "man' have been called gender-neutral even though there is a lot of dispute about the truth content of that claim. For instance, the word 'man' could refer to either, a person or persons of unknown sex, or males or a combination of males and females. This concealment is at the heart of the matter of language and gender studies.

The whole discussion about language and gender neutrality still percolates to the war of the sexes advanced by feminism as a movement. There seems to be a widespread suspicion of every motive and action of the men by the women; hence trust seems to have been eroded. This is why Spender (1985) could write: "the word for women assume(s) negative connotations even when/where it designated the same state or condition as it did for men" (p.17).

However, going past this suspicion and distrust, it is important to state that beyond certain pronouns and metaphors that are seen as gender sensitive, there is nothing actually wrong if gender is expressed in language based on the personality trait. This personality trait, we must clearly state, can be influenced by a lot of factors ranging from environmental to cultural, social/peer relationship, family, associations etc. This is what informs gender language and there is nothing wrong in that as it is peculiar to the male and female folk alike. This should not be misrepresented especially when undermining the women. These and related issues shall be our next focus.

\section{Feminist Language and its Justification}

Feminist language is the totality of the way in which the women express themselves especially from their reference frame as women. This does not have to do with the words they employ even though that to some considerable extent is important. But it is basically hinged on their sexuality (not biological now parse) and their perception of reality as women. Glass (1993) gives more insight into this thus:

The fact that many men and women continue to communicate in sexual stereotypes perpetuates these problems in our society today. The way in which both men and women have been raised, conditioned, and socialized has created genuine and sometimes insurmountable communication problems for both sexes. We take for granted that the opposite sex understands us, yet it has been clearly proven that men and women do not communicate in similar ways (p.16).

If men and women do not communicate in similar ways, that means a lot of factors could be accountable for it. Hence, it will not be rational for these factors to be overlooked while at the same time blaming either sex for acting or reacting in a certain way. For example, Glass(1993) gives what she calls sex-talk Quiz. Amongst them 
are some claims like:

Women are "talkers". They talk much more than men in group conversations. Women are more complimentary. They give more praise than men. Women give more orders and are more demanding in the way they communicate.Women and men are equally emotional when they speak (30).

These and many more are reasons why women are perceived differently and misrepresented and this is widespread especially by the men-folk. The behaviourists or put differently, psychologists understand better to some extent that behaviours are often classified by perception or experience; even though perception alone is not enough as there are undercurrents behind every behavioural pattern. This is why the cases are all proven to be false except the one which says that: women are more complimentary; they give more praise than men, by the analysis carried out by Glass(1993). Even though all these theories are true, it still doesn't undermine the position of the women as there are distinct peculiarities that characterize the nature of our being as male or female.

Gender studies, especially with respect to language, is apt in that it goes beyond just understanding the way both sexes communicate and the importance placed on words used. This is where it becomes easy to enforce one's superiority above the other. Mapstone (1998), writing along this line avers that:

Early on in my investigations into the psychology of argument, I asked people what they thought about argument, and whether it is a good way to get people to see your point of view. Their replies made it clear that women and men don't see argument in the same way (p.20).

This is the point that is too salient to be ignored. Not seeing things from the same point of view has an undercurrent that goes beyond the peripheral. The stern position at one's conviction must have something to do with the personality of the person involved; and like it has been established in passing, it may not necessarily be biological but social and environmental. Thus, we have the cases of some women acting more like men and the case of some men acting more like women.

One of the subtle reasons that is responsible for the way that language is used during communication, expression or argument is "pressure" occasioned by being at a disadvantage. Pressure goes with a lot of tendencies that makes us act in ways unimaginable. Mapstone (1998) avers further:

In formal non-work relationships, however, high levels of anger, aggression and threats of violence are mainly directed at women - by both men and women. This difference extends even to neighbours,... anger is very near the surface and ready to explode... (p.201).

From Mapstone's submission, we can see that this issue of pressure leading to anger and aggression is not the exclusive preserve of any gender. It is something that runs through both the male and the female hence should not be amplified when the women seem to be at the fore. Nonetheless, in other quarters, women have been labeled as being very loving, caring, patient, dutiful and always desiring that their male counterparts understand their emotional leaning and that they are not asking for too much other than to be understood. This claim perhaps led to Gray's (1993) controversial opinion that, "women intuitively understand that to have a good relationship, you have to work at it. Men, on the other hand, are born with the knowledge that at your job, that's where you work" (p.ix).

At this juncture, it is pertinent to ask: why are women easily accused or perceived as being too erratic, emotional and unstable in their words or actions? This, of course, is the kind of perception amongst others that portrays women as being misunderstood and misrepresented by men leading to the feminist movement. However, it must be stressed that apart from biological differences, most women believe that the era of men's supposed superiority over the women is long gone. There is even the belief that women are more important than men, and can do by far better what men can do. Gray (1993) gives us another perspective about this:

Accepting our psychological differences, frees us to experience an underlying oneness that permeates our relationships. In an abstract way, we are all the same. In every spiritual teaching is an acknowledgement of that oneness... This opening of the heart is an awareness that what is outside us 
is also inside us (p.3).

The truth to be exhumed from Grays' submission is that despite the behavioral traits peculiar to men and women which intersect, the inadequacy of one complements the adequacy of the other because there are inadequacies that can be found in being a man or a woman. There are also inadequacies to be found in not being a man or a woman. Hence, if we hold on to these inadequacies, we sooner or later, realize our own inadequacies that need some assistance.

When we dwell so much on the shortcomings and misgivings of either sex, we become clouded with patterns that make us miss the point that men/women complement each other. Understanding this will quell the cold war that feminism breeds in its totality. However, feminist language is important because it expresses the personality of the women in communication thereby bringing out in a clearer manner, the way in which she sees the world, and as Tingley(1994) will say: "Yes, women are suddenly winning the battle of the sexes, but the real war is another matter".

\section{Conclusion}

This work has been an effort to contribute to the on-going debate on feminism. Even though the work focuses on the angle of feminist language, it nevertheless touches on a new perspective in understanding why men and women talk and act the way they do. The discussion here is not exhaustive, but doubtless opens up further discourse in understanding the dynamics of the cold war of the sexes.

One of the novel ideas of this research is the finding that the biological factor of both men and the women is not so much responsible as to the reason why men and women talk and act the way they do as we can have a woman biologically who is more a man in expression and a man biologically who is more a woman in expression. Thus, as we conclude, one vital recommendation that is deduced from the work is that both sexes (male/female) complement each other rather than diminish each other.

\section{References}

Baron, D. (1986). Grammar and Gender. New Haven: Yale University Press.

Calvet, L. (1998). Language, Wars and Linguistic Politics. Oxford: University Press.

Coates, J. (2004). Women, men and language. London: Longman.

De Beauvoir, S. (1970). The Second Sex. Trans. \& Ed. H.M Parsley. New York: Bantan

Frye, M. (1983). The Politics of Reality: Essays in Feminists Theory Freedom. California: The Crossing Press.

Glass, L. (1993) He Says, She Says: Closing the Communication Gap Between the Sexes. New York: Perigee Books.

Gray, J. (1993). Men, Women and Relationships. Oregon: Beyond Words Publishers.

Holmes, J. (1984). An Introduction to Sociolinguistics. London: Longman.

Lakoff, R. (1975). Language and Woman's Place. New York: Harper Colophon Books

Mapstone, E. (1998).War of Words: Women and Men Arguing. London: Chatto and Windus

Ojong, K. A. (2011). A Refutation of Private Language Epistemology. Calabar: Jochrisam

Quine, W.V.O (1953). Ontological Relativity and Other Essays. Cambridge: Harvard University Press.

Spender, D. (1985). Manmade Language. New York: Routledge

Tingley, J. C. (1993). Gender Flex: Men and Women Speaking each other's Language at Work. New York: Amacom Press

Uma, N. (1999). The Project of Feminist Epistemology: Perspectives from a Non-Western Feminist In Kit, C. R. (ed.) Philosophy and Choice California: Mayfield Publishers. 